\title{
Option Trading, Information Asymmetry and Firm Innovativeness: Evidence from Stock Options Trading Firms from India
}

\author{
Himanshu Joshi \\ FORE School of Management, New Delhi, India \\ Email: himanshu@fsm.ac.in
}

How to cite this paper: Joshi, H. (2018) Option Trading, Information Asymmetry and Firm Innovativeness: Evidence from Stock Options Trading Firms from India. Theoretical Economics Letters, 8, 2169-2181. https://doi.org/10.4236/tel.2018.811142

Received: June 19, 2018

Accepted: August 4, 2018

Published: August 7, 2018

Copyright $\odot 2018$ by author and Scientific Research Publishing Inc. This work is licensed under the Creative Commons Attribution International License (CC BY 4.0).

http://creativecommons.org/licenses/by/4.0/

\section{(c) (i) Open Access}

\begin{abstract}
Present study examines the effect of option listing and subsequent trading on the innovation in the context of publicly listed Indian firms. Innovation is defined in terms of input and output as R \& D expense to sales, and number of patents filed by firm, respectively. Multiple regression analysis is conducted to identify drivers of innovations. Measures of innovation are used as dependent variables, while dummy for option trading is taken as independent variable along with other firm level control variables. The study also examines the determinants of the option listing on individual stocks using binary-logistic regression. Firm age, financial leverage, dividend payout, and profitability affect internal R \& D allocations for the sample firms. As far as firm's research output is concerned, firm leverage, institutional holding, option trading, and ESOP are the major determinants. Firm leverage adversely affects R \& D input and R \& D output alike. Dividend paying, large firms having higher institutional holdings are likely to attract stock option listing, while firms with high firm specific return variations are likely to have very low probability of option listing.
\end{abstract}

\section{Keywords}

Stock Options, Firm Innovativeness, Information Asymmetry, Logit

Regression

\section{Introduction}

Well developed and efficient capital markets not only improve the efficiency of long-term resource allocation but also improve firm's governance practices through their monitoring and disciplining mechanisms. However, in recent 
years financial markets have witnessed extraordinary growth in shareholder activism. These shareholder activists take minority equity positions in public companies they believed to be undervalued or underperforming — and then work to increase their profitability and value by proposing changes in their overall strategy or in their operating and financial policies. Such activist investors, although mainly a force for economic efficiency, have the potential to produce short-sighted cutbacks in corporate investment. Therefore, capital markets on one hand limit agency costs through corporate raiders and activist investors, on the other side, they also mount enormous pressure on the firm management to meet quarterly or annual financial objectives, which gives rise to adverse externalities that may impair firm's incentives to innovate [1] [2]. Combinations of factors like quarterly disclosure norms, activist investors, enhanced and impeding coverage by analysts, and demanding money managers make it challenging for the corporate managers to focus on the long term growth. Many firms in United States and Europe have responded to these challenges by going private (Berger King, Dell, and Reader's Digest to name a few). However, going private is not a viable option in the context of $\mathrm{R} \& \mathrm{D}$ intensive firms in emerging markets. These firms require enormous amount of risk capital to carry out research and development activities, which can be raised only through the public offering of stocks. Moreover, unlike developed markets, the penetration of private equity firms and venture capitalists is quite low in emerging markets. Therefore, for $\mathrm{R}$ $\&$ D intensive firms operating in emerging markets, the panacea should come from the financial markets only. Optimism comes from another facet of the financial market, namely, financial derivative market. Literature suggests that trading of equity options written on the individual stocks can spur firm innovation by reducing information asymmetry related to long term investment like $\mathrm{R}$ \& D.

The primary objective of the introduction of financial derivatives is to provide investors with an opportunity to hedge risk. Derivatives also increase liquidity of the underlying asset market, thereby making it more information efficient. Unlike futures, which is a contract to buy (or sell) the underlying asset at a certain price during the life or on expiration of the contract and under which both the parties are under obligation to honor the contract; an option gives the holder of that option right to buy (or sell) the underlying asset in predetermined quantities for a certain price at any time during its life or on its expiry date. Pricing or value of an option depends greatly on the volatility of the underlying asset, in addition to the other factors like time to expiration, risk free rate of interest, exercise price, and spot rate. In fact, options on highly volatile underlying assets, attract higher price in option trading. In competitive and frictionless market, option payoff can be replicated with that on a portfolio of the underlying stock and a risk free bond, and in such a complete market, trading of option should have no impact on the underlying stock [3]. However, actual markets are incomplete and far from perfection, and in such markets options listing and sub- 
sequent trading may affect the underlying asset market behavior, including their prices, liquidity, and volatility. Ross [4] and Hakansson [5] show that options listing and trading complete the market by providing the investors with hedging opportunities. In the presence of information asymmetry under incomplete markets, increased hedging transactions can reduce the probability of trading against informed traders for uninformed traders. Black [3] argues that presence of option contracts can increase the informed trading in the underlying assets by providing higher leverage to financially constrained traders. Option trading also supports informed trading by relaxing the short-sale constrained on the individual stocks [6] and Johnson and So [7]. Also, Cao [8] reports that option trading motivates less informed investors to gather more private information about the underlying stocks. Such private information is especially relevant for long term investments, and trading on such information makes underlying stock market more efficient [9] [10]. If stock prices are more efficient, then less-informed investors learn more about the fundamental value of the firm, which reduces informational asymmetry problems related to long term investments by the firm like $\mathrm{R} \& \mathrm{D}$ activities, and patents under work in progress.

Paper intends to examine effect of option listing and subsequent trading on the innovation in the context of publicly listed Indian firms. Options trading is available on 175 individual stocks (stipulated by SEBI) on national stock exchange (NSE). Innovation is defined in terms of input as R \& D expense to sales ratio, and output as number of patents filed by a company. Multiple regression analysis is conducted to identify drivers of innovations. Measures of innovation are used as dependent variables, while dummy for option trading is taken as independent variable along with other control variables. The study also examines the determinants of the option listing on individual stocks in India using logistic regression.

The remainder of the paper is organized as follows. Section 2 discusses the related literature. Section 3 describes the sample, and measurement of variables. In Section 4 presents the findings and analysis. Finally, Section 5 concludes the findings.

\section{Literature Review}

Black and Scholes [3] and Merton [11] argue that in frictionless competitive market, derivative contracts like options and futures are of no use, and their payoffs can be replicated using portfolio of underlying stock and a risk free bond. However, it is well documented in finance literature that capital markets are incomplete, and exhibit information asymmetry. Ross [4] was the first to argue that options trading can convey important information in a market with information asymmetry by expanding the contingencies that are covered by traded securities. Options trading complete the market and reduce information asymmetry in following three ways-by providing leverage to financially constrained 
informed investors, by relaxing short sale constraints on stocks, and by motivating informed investors to gather private information about the underlying stocks. Investors use option contracts for hedging purposes, which increase the trading demand in the underlying asset market [4] and Hakansson [5]. In the presence of information asymmetry under the incomplete market conditions, increased hedging transactions can reduce the probability of informed trading by the investors. Black [3] argues that options trading can improve the volume of informed trading by providing higher leverage to informed traders who are financially constrained. Easley, O'Hara and Srinivas [12] argue that options can be more attractive for informed traders because the availability of multiple contracts confronts uninformed traders with substantial challenges. Cao [8] shows that option trading motivates uninformed investors to gather more private information about the underlying stock/firm, which in turn lead to improved price informativeness. Such private information is especially relevant for long term investments, and trading on such information make underlying stock market more information efficient. Additionally, option trading provides investors with information about stock price volatility [13]. These notions are further supported by Chakravarty, Gulen and Mayhew [9] and Pan and Poteshman [10], who also found that option trading volume contain information about the future direction of the underlying asset. Therefore, this branch of literature suggests that option trading completes the market for underlying stocks, and reduce information asymmetry.

Another branch of literature establishes links between price informativeness and investment decisions in the firm. The notion behind the linkage of price informativeness and investment decisions in the firm is that generation and aggregation of information as a consequence of trading between uninformed traders and informed investors can be useful for the provision of incentives in firms. Holmstrom and Tirole [2] and Faure-Grimaud and Gromb [14] examine the role of price informativeness in disciplining managers and providing incentives to insiders to engage in value-increasing activities. Gehrig [15] show that cross-listing enables firms to obtain more precise information on the value of their growth opportunities, which allows managers to make better investment decisions. Ferreira and Raposo [16] provide evidence that if prices are more efficient, the stock market is able to play a monitoring role that can reinforce internal and external monitoring mechanisms. Dow and Gorton (1997) show that, in equilibrium, the information contained in stock prices can be used to guide investment decisions in the firm because managers are compensated based on future stock prices. Several other studies also accomplish that resources are allocated more efficiently if prices convey more information, which leads to greater valuation for the firm [17] [18] [19] [20]. More recently, Blanco and Wehrheim [21] relate reduced information asymmetry due to option trading to firm innovative. They argue that a potential solution to the distortion of innovative investment due to agency problems is active options markets, and that for firms 
that are listed on options markets, greater trading activity is associated with an increased propensity to innovate. In the Indian context, there is little empirical evidence about the impact of option listing on information asymmetry, and subsequent informed trading. Joshi [22] investigated the impact of single stock option trading on the volatility of the underlying stocks in Indian market using data of companies listed on National Stock Exchange (NSE) of India. Findings of his study suggest that for the large cap firms, volatility increases after the option listing. Also, study reports statistically insignificant decline in the daily variance and average long-run volatility for mid cap, and small cap firms. This increase in volatility can lead to increased informed trading in the stocks on which options are listed.

Present study examines the effect of option listing and subsequent trading on firm innovation in the context of publicly listed Indian firms. This study is a worthwhile attempt as there is no such study conducted in context of any emerging market. Moreover, emerging markets differ substantially from the developed markets in terms of information asymmetry and propensity of informed trading, and no empirical evidence is available about the impact of option listing on informed trading and firm innovation in these markets.

\section{Data and Methodology}

\subsection{Sample}

Paper intends to examine effect of option listing on the innovation in the context of publicly listed Indian firms. Options trading is available on 175 individual stocks (stipulated by SEBI) on national stock exchange (NSE). Innovation can be defined in terms of input and output. No. of patents filed by a company define the innovation output, while $\mathrm{R} \& \mathrm{D}$ expense to sales ratio define the innovation input for the firm. Initially, cross section data for financial year 2016-17 was collected for Nifty 500 companies from CMIE (Centre for Monitoring Indian Economy) prowess database. However complete data for all the variables (dependent, and independent including control variable) was available for only 208 firms. Out of these 208 firms, option trading is active on 89 firms. Information on patents filed by firms has been collected from Indian patent office.

\subsection{Model Specification}

Linear multiple regression analysis is conducted using innovation input ( $R$ \& $D$ expense to sales ratio), and innovation output (number of patents filed by the firm) as dependent variables, and option trading dummy as independent variable. Dummy variables are used for the option trading and ESOPs. Dummy variable of option trading will take value of 1 if stock options are available for the firm, otherwise 0. Various independent variables which may influence the innovation input and output of a firm are identified from the literature, and are used in multiple regression as control variables. Control variables used in analysis are institutional ownership, firm size, debt ratio, operation profit margins, net sales 
volatility, firm age etc. A dummy variable is used for employee stock option offered by the firms. Dummy variable of ESOP will take value of 1 if firms have issued ESOPs, otherwise 0 .

$$
\begin{aligned}
& \text { Innovation Input }(\mathrm{R} \& \mathrm{D} \text { Expense/Sales }) \\
&= \beta_{0}+\beta_{1}(\text { Firm_Age })+\beta_{2}(\text { Institutional Ownership }) \\
&+\beta_{3}(\text { Firm_Size })+\ldots+\beta_{j}(\text { Dummy_Option Trading }) \\
&+\beta_{k}(\text { Dummy_ESOP })+\varepsilon_{i} \\
& \text { Innovation Input }(1+\text { No. Patents }) \\
&=\beta_{0}+\beta_{1}(\text { Firm_Age })+\beta_{2}(\text { Institutional Ownership }) \\
&+\beta_{3}(\text { Firm_Size })+\ldots+\beta_{j}(\text { Dummy_Option Trading }) \\
&+\beta_{k}(\text { Dummy_ESOP })+\varepsilon_{i}
\end{aligned}
$$

Binary logistic regression analysis is conducted to study the determinants of option listing on individual stocks in India. A dummy variable for option listing is specified as dependent variables, and stock return volatility, dividend payout ratio, dummy of employee stock option, firm age in years, measure of illiquidity, percentage of institutional ownership, natural logarithm of market capitalization, and R \& D to total asset ratios are specified as independent variables.

$$
\begin{aligned}
\text { Dummy_Option Trading }= & \beta_{0}+\beta_{1}(\text { Stock Return Volatility })+\beta_{2}(\text { Dividend Payout Ratio }) \\
& +\beta_{3}(\text { ESOP_Dummy })+\beta_{4}(\text { Firm Age })+\beta_{5}(\text { Firm Specific Return Variation }) \\
& +\beta_{6}(\text { Institutional Ownership })+\beta_{7}(\text { Firm_Size })+\beta_{8}(\text { R\&D/Total Assets })+\varepsilon_{i}
\end{aligned}
$$

Firm specific stock return variation is measured by regressing stock returns with the market returns, and firm specific return variation is estimated by $1-R_{2}$ from the regression. Given the bounded nature of $R_{2}$, a logistic transformation has been computed as follows:

$$
\Psi=\log \left[\left(1-R_{2}\right) / R_{2}\right]
$$

The variable $\Psi$ measures firm-specific stock return variation relative to market-wide variation, or lack of synchronicity with the market.

\section{Findings and Analysis}

Table 1 provides summary statistics of the main variables used in this study for sample of firms without stock option trading and for the sample of firms having stock option trading. Out of total 208 firms, only 89 firms have stock option trading, while 119 firms do not have stock option trading. Option trading firms are larger (market capitalization), older (firm age), marginally higher on research expenditures, more cross listed, having higher institutional holding, marginally less leveraged, more liquid, less volatile, generating higher return on assets, and paying higher dividends in comparison to non-option trading firms. It is evident from Table 1 that propensity to research (as described by R \& D 
Table 1. Summary statistics for variables constructed based on the sample of Indian publicly traded firms without and with active option trading.

(A)

\begin{tabular}{ccccccc}
\hline $\begin{array}{c}\text { A. without active option } \\
\text { trading }\end{array}$ & Mean & Median & Std. Dev & Min & Max & Observations \\
\hline $1+$ R \& D/Sales & 1.010 & 1.004 & 0.018 & 1.000 & 1.148 & 119 \\
Firm age & 25.728 & 26.449 & 10.290 & 1.940 & 36.934 & 119 \\
Institutional Holding percentage & 0.430 & 0.425 & 0.157 & 0.100 & 1.000 & 119 \\
Equity dividend as \% of PAT & 17.568 & 10.050 & 25.693 & 0.000 & 159.150 & 119 \\
R \& D (\% of Total Assets) & 0.010 & 0.004 & 0.018 & 0.000 & 0.148 & 119 \\
Return on total assets & 8.972 & 8.360 & 5.547 & -0.500 & 34.110 & 119 \\
Financial Leverage & 0.393 & 0.140 & 0.693 & 0.000 & 6.140 & 119 \\
ESOP Dummy & 0.328 & 0.000 & 0.471 & 0.000 & 1.000 & 119 \\
Cross Listing & 0.084 & 0.000 & 0.279 & 0.000 & 1.000 & 119 \\
Firm Specific Return Variation & 0.303 & 0.128 & 0.557 & 0.001 & 4.807 & 119 \\
365 days Returns Volatility & 2.103 & 2.030 & 0.515 & 0.950 & 3.940 & 119 \\
Market Capitalization & 8.629 & 8.537 & 0.800 & 6.861 & 11.073 & 119 \\
\hline
\end{tabular}

(B)

\begin{tabular}{ccccccc}
\hline B. with active option trading & Mean & Median & Std Dev & Min & Max & Observations \\
\hline 1 + R \& D/Sales & 1.013 & 1.004 & 0.021 & 1.000 & 1.128 & 89 \\
Firm age & 28.150 & 25.222 & 14.235 & 1.841 & 80.164 & 89 \\
Institutional Holding percentage & 0.500 & 0.479 & 0.167 & 0.250 & 1.000 & 89 \\
Equity dividend as \% of PAT & 35.081 & 28.440 & 32.416 & 0.000 & 178.320 & 89 \\
R \& D (\% of Total Assets) & 0.013 & 0.004 & 0.021 & 0.000 & 0.128 & 89 \\
Return on total assets & 10.576 & 8.280 & 8.659 & -4.360 & 38.130 & 89 \\
Financial Leverage & 0.374 & 0.110 & 0.640 & 0.000 & 3.930 & 89 \\
ESOP Dummy & 0.506 & 1.000 & 0.503 & 0.000 & 1.000 & 89 \\
Cross Listing & 0.236 & 0.000 & 0.427 & 0.000 & 1.000 & 89 \\
Firm Specific Return Variation & 0.032 & 0.014 & 0.062 & 0.000 & 0.473 & 89 \\
365 days Returns Volatility & 1.796 & 1.740 & 0.413 & 1.110 & 3.760 & 89 \\
Market Capitalization & 10.323 & 10.462 & 1.237 & 7.505 & 13.080 & 89 \\
\hline
\end{tabular}

Source: Table constructed by the author using firm level data from CMIE Prowess data base.

expense to total asset ratio and $1+\mathrm{R} \& \mathrm{D}$ expense to sales ratio) has a positive connotation with stock option trading.

Firms with active option trading attract higher institutional ownership, have higher propensity of issuing employee stock options and are more cross listed. Issuing employee stock options help reduce the cost of agency conflicts between shareholders and managers. Cross listing results into compliance with the high quality disclosure and governance norms. Higher institutional ownership sup- 
ports more informed trading in the underlying stock market. Reduced information asymmetry is also evident from substantially lower value of firm specific return variation for option-trading firms in contrast to non-option trading firms.

Table 2 presents the results of regression for R \& D input and R \& D output on option trading dummy and other control variables. Control variables include firm leverage, dividend payout ratio, firm age, institutional holding, return on assets, option trading dummy, and ESOP dummy. Second column of Table 2 present the result of regression for $\mathrm{R} \& \mathrm{D}$ input on option trading dummy and other control variables, while third column presents the result for R \& D output on the same independent and control variables. However, there are marginal differences in terms of research indulgence, firm age, and financial leverage between the two set of firms.

Typically, research projects are financed through internal accruals. If internal accruals are not available, firms normally resort to external equity financing. However, debt is seldom used in such projects. Therefore level of firm leverage is an important determinant for firm innovativeness. According to dividend signaling hypothesis, dividend payments convey significant message to financial markets about the authenticity of firm's profitability. Therefore dividend payment reduces the informational asymmetry. Employee stock options work as proxy for lower agency conflicts. Institutional holding work as a double edged sword. On one hand, higher institutional holdings may provide the firm with

Table 2. Heteroscedasticity-consistent regression results for $\mathrm{R} \& \mathrm{D}$ Input and $\mathrm{R} \& \mathrm{D}$ output on option trading dummy and other control variables. $\left({ }^{*} \mathrm{p}<0.10,{ }^{* *} \mathrm{p}<0.05,{ }^{* * *} \mathrm{p}\right.$ $<0.01$.)

\begin{tabular}{ccc}
\hline & OLS & OLS \\
& $\begin{array}{c}\text { R\&D Input (1+ R \& D } \\
\text { Exp/Sales) }\end{array}$ & $\begin{array}{c}\text { R \& D Output (1+ Number of } \\
\text { Patents) }\end{array}$ \\
\hline Adjusted $R_{2}$ & 0.0716 & 0.5518 \\
F-Statistic & 3.2832 & 37.4091 \\
Prob (Wald F-Statistics) & $0.0112^{\star * *}$ & $0.0000^{* * *}$ \\
C & 1.0132 & 0.7648 \\
& $192.254^{* * *}$ & $2.0240^{* * *}$ \\
Firm Leverage & -0.0030 & -0.2458 \\
& $-2.5622^{* * *}$ & $-1.6311^{*}$ \\
Dividend Payout & $-6.47 \mathrm{E}-05$ & -0.0001 \\
& $-1.7455^{*}$ & -0.0492 \\
Firm Age & -0.0002 & -0.00412 \\
& $-1.9341^{* *}$ & -0.6033 \\
Institutional Holding & -.0030 & -1.0964 \\
& -0.4293 & $-2.0233^{* *}$ \\
Return on Assets & 0.0004 & -0.0090 \\
& $2.0166^{* *}$ & -0.6723 \\
Option Trading Dummy & 0.0032 & 2.4996 \\
& 1.2417 & $12.1518^{* * *}$ \\
ESOP Dummy & 0.0036 & 0.2595 \\
& 1.4336 & $1.6141^{\star}$ \\
\hline
\end{tabular}

Source: Table generated using Eviews 8 for result of multiple regression analysis. 
required risk capital for research projects, on the other hand it may stimulate short termism in the firm's decision making. Therefore, it is interesting to verify its role in research input and output. Firm's age and profitability can also influence its research activities.

For R \& D input regression, firm age, firm leverage, dividend payout, and return on assets are statistically significant, while option trading dummy is not. Option trading dummy has a positive but statistically insignificant coefficient, which indicates that option trading improves the intercept for firm's research and development activities. Similar, indicative results are plausible for ESOP dummy as well. Negative coefficient of firm age depicts that older firms make less provision for research activities than the relatively newer firms. Firm leverage also have a negative coefficient, which is in line with findings of the existing literature that highly leveraged firms tend to spend less on R \& D activities, or in other words, R \& D expenses are predominantly equity financed. Dividend payout ratio also has a negative albeit extremely small value. Return on asset have positive and significant coefficient, displaying that profitable firms allocate more towards R \& D activities. Another interesting outcome is the negative coefficient (albeit, statistically insignificant) of institutional holding. Intuitively, this depicts that higher institutional holding intensify short term focus, which results into lower allocation of funds for research and development activities.

For R \& D output regression, firm leverage, institutional holding, option trading dummy, and ESOP dummy are statistically significant. However, dividend payout, firm age, and return on assets are not statistically significant. Dummy variables for option trading and ESOP have positive and significant coefficient. The intercept of the regression equation would increase substantially in the presence of these two dummy variables. Value of intercept is 0.7648 , which shows the average number of patents filed by the sample firm in absence of any independent variable. Adding coefficient of dummy variable for option trading would escalate the intercept value to 3.2644. In addition, if coefficient of dummy variable for ESOP has to be added, then intercept value would escalate to 3.5239. Hence, average number of patents filed by an option trading would be 3.2644 , and it would be 3.5239 for a firm having ESOPs along with the option trading. Therefore, both option trading and ESOPs have substantial impact on R \& D output of the firms. Analogous to the R \& D input, financial leverage also have negative and stronger influence on $\mathrm{R} \& \mathrm{D}$ output, demonstrating that low leveraged firms are better positioned to generate better research output. Institutional holding also have negative and statistically significant coefficient, inferring short term focus of institutional investors, resulting into lower R \& D output. Interestingly, variables of firm age, and return on asset which have statistically significant coefficient for R \& D input, have insignificant coefficients for R \& D output. Therefore, firm age and profitability does not influence the research output for sample firms.

Table 3 presents the results of binary-logit regression for option trading 
Table 3. Results of binary-logit regression for option trading dummy on independent variables. $\left({ }^{\star} \mathrm{p}<0.10,{ }^{* *} \mathrm{p}<0.05,{ }^{* *} \mathrm{p}<0.01\right.$.)

\begin{tabular}{cc}
\hline & $\begin{array}{c}\text { Binary Logit (Quadratic hill climbing) } \\
\text { Option }\end{array}$ \\
Trading Dummy
\end{tabular}

dummy on underlying stock return volatility, dividend payout, firm age, institutional holdings, market capitalization, illiquidity, R \& D to total assets, and cross listing dummy. Since, pricing or value of an option contract depends greatly on the volatility of the underlying asset, volatile stocks are likely to have higher probability of option listing. Dividend payout and cross listing dummy are proxies for lower information asymmetry and better disclosure respectively. R \& $\mathrm{D}$ expenses to total assets denote intensity of fund allocation for research projects. Institutional holding is related to informed investments in the firm. Institutional investors are likely to benefit from stock option trading, as it holds information about the future direction of the underlying asset. The variable $\Psi$ measures firm-specific stock return variation relative to market-wide variation, or lack of synchronicity with the market. Firm age, and market capitalization are used as control variables.

Under binary-logit regression, coefficients of independent variables indicate probability of stock option listing. Stock return volatility, and firm age have negative coefficients, showing negative influence on probability of stock option listing. R \& D expense to total assets has coefficient, showing higher option listing probability for a research intensive firm. However, coefficients of stock return volatility, firm age, and $\mathrm{R} \& \mathrm{D}$ expense to total assets are statistically insignificant, therefore results are only indicative. Dividend payout, institutional holding, market capitalization, illiquidity, and dummy for cross listing have statistically significant values. Positive coefficient of dividend payout demonstrates that the firms paying higher fraction of their profit as dividend are more likely to attract stock option listing. Institutional holding have highly positive coefficient, indicating firms with higher institutional ownership are more likely to get op- 
tion listing. Result confirms the assumption that institutional owners are likely to benefit from information generated by option trading about the future direction of the underlying stock prices. Positive coefficient of market capitalization demonstrates higher probability of option listing for larger firms. Coefficient of firm specific stock return variation have extremely large negative value, indicating an extremely low probability of option listing for the firms having lack of information synchrony with the market. French and Roll [23] and Roll [24] suggests that firm specific return variation measures the rate of private information incorporated in the stock prices via trading. Therefore, stock prices of the firms having higher firm specific return variations hold more private information. Such firms have low probability of option listing, however, option listing on these firm may result into information aggregation and dissemination through the option trading route and more market aligned and efficient stock prices.

\section{Conclusion}

The template is designed so that author affiliations are not repeated each time for study finds that higher institutional ownership along with higher propensity of issuing employee stock options and cross listing status exemplifies reduced information asymmetry for option trading firms. Firm age, financial leverage, dividend payout, and profitability affect internal R \& D allocations for the sample firms. Option trading dummy is a positive but insignificant factor for firm's research and development inputs. Older firms make less provision for research activities than the relatively newer firms. As far as firm's research output is concerned, firm leverage, institutional holding, option trading, and ESOP are the major determinants. It is interesting to note that option trading is affecting $\mathrm{R} \&$ $\mathrm{D}$ output more potently than the firm level internal allocation of funds to the $\mathrm{R}$ \& D expenses. Firm leverage adversely affects R \& D input and R \& D output alike. Probability of stock option listing depends on dividend payout, institutional holding, size of the firm, cross listing status of the firm, and firm specific stock return variations. With dividend paying, large firms having higher institutional holdings are likely to attract stock option listing, while firms with high firm specific return variations are likely to have very low probability of option listing. R \& D intensive firms with unique and complex product offerings would benefit from reduced information asymmetry by active options trading on their stocks. Therefore, regulator (SEBI) should promote sponsored stock option listing for the firms qualified under the stipulated conditions. Also, firms with high propensity of research and development activities, or having unique and complex product offerings should consider stock option listing, as active option trading would result into improved informed trading in their stock, and reduced information asymmetry pertaining to long term complex investments. There is scope of further research associated with option trading and information asymmetry, and informed trading in emerging markets using data of option trading 
volume.

\section{Conflicts of Interest}

The authors declare no conflicts of interest regarding the publication of this paper.

\section{References}

[1] Holmstrom, B. (1999) Managerial Incentive Problems: A Dynamic Perspective. The Review of Economic Studies, 66, 169-182. https://doi.org/10.1111/1467-937x.00083

[2] Holmstrom, B. and Tirole, J. (1993) Market Liquidity and Performance Monitoring. Journal of Political Economy, 101, 678-709. https://doi.org/10.1086/261893

[3] Black, F. (1975) Fact and Fantasy in the Use of Options. Financial Analysts Journal, 31, 36-72. https://doi.org/10.2469/faj.v31.n4.36

[4] Ross, S. (1976) Options and Efficiency. The Quarterly Journal of Economics, 90, 75-89. https://doi.org/10.2307/1886087

[5] Hakansson, H. (1982) Changes in Financial Market: Welfare and Price Effects and the Basic Theorems of Value Conversion. The Journal of Finance, 37, 977-1004. https://doi.org/10.1111/j.1540-6261.1982.tb03592.x

[6] Figlewski, S. and Webb, G. (1993) Options, Short Sales, and Market Completeness. The Journal of Finance, 48, 761-778. https://doi.org/10.2307/2328923

[7] Johnson, L. and So, E. (2012) The Option to Stock Volume Ratio and Future Returns. Journal of Financial Economics, 106, 262-286. https://doi.org/10.1016/j.jfineco.2012.05.008

[8] Cao, H. (1999) The Effect of Derivative Assets on Information Acquisition and Price Behavior in a Rational Expectations Equilibrium. Review of Financial Studies, 12, 131-163. https://doi.org/10.1093/rfs/12.1.131

[9] Chakravarty, S., Gulen, H. and Mayhew, S. (2004) Informed Trading in Stock and Option Market. The Journal of Finance, 59, 1235-1257.

https://doi.org/10.1111/j.1540-6261.2004.00661.x

[10] Pan, J. and Poteshman, A. (2004) The Information of the Option Volume for Future Stock Prices. NBER Working Paper No. 10925. http://www.nber.org/papers/w10925 https://doi.org/10.3386/w10925

[11] Merton, R. (1973) An Intertempoal Capital Asset Pricing Model. Econometrica, 41, 867-887. https://doi.org/10.2307/1913811

[12] Easley, D., O’Hara, M. and Srinivas, P. (1998) Option Volume and Stock Prices: Evidence on Where Informed Traders Trade. The Journal of Finance, 53, 431-465. https://doi.org/10.1111/0022-1082.194060

[13] Ni, S., Pan, J. and Potashman, A. (2008) Volatility Information Trading in the Option Market. The Journal of Finance, 63, 1059-1091. https://doi.org/10.1111/j.1540-6261.2008.01352.x

[14] Faure-Grimaud, A. and Gromb, D. (2004) Public Trading and Private Incentives. Review of Financial Studies, 17, 985-1014. https://doi.org/10.1093/rfs/hhh002

[15] Gehrig, T. (2008) The Internationalization of Asset Ownership in Europe. Economica, 75, 799-800. https://doi.org/10.1111/j.1468-0335.2008.00711.x

[16] Ferreira, D., Ferreira, M. and Raposo, C. (2011) Board Structure and Price Informa- 
tiveness. Journal of Financial Economics, 99, 523-545.

https://doi.org/10.1016/j.jfineco.2010.10.007

[17] Khanna, N., Slezak, S. and Bradley, M. (1994) Insider Trading, Outside Search, and Resource Allocation: Why Firms and Society May Disagree on Insider Trading Restrictions. Review of Financial Studies, 7, 575-608.

https://doi.org/10.1093/rfs/7.3.575

[18] Subramanyam, A. and Titman, S. (1999) The Going-Public Decision and the Development of Financial Markets. The Journal of Finance, 54, 1045-1082. https://doi.org/10.1111/0022-1082.00136

[19] Durnev, A., Morck, R. and Young, B. (2004) Value-Enhancing Capital Budgeting and Firm-Specific Stock Return Variation. The Journal of Finance, 59, 65-105. https://doi.org/10.1111/j.1540-6261.2004.00627.x

[20] Chen, Q., Goldstein, I. and Jiang, W. (2007) Price Informativeness and Investment Sensitivity to Stock Price. Review of Financial Studies, 20, 619-650. https://doi.org/10.1093/rfs/hhl024

[21] Blanco, I. and Wehrheim, D. (2017) The Bright Side of Financial Derivatives: Options Trading and Firm Innovation. Journal of Financial Economics, 125, 99-119. https://doi.org/10.1016/j.jfineco.2017.04.004

[22] Joshi, H. (2018) Does Introduction of Stock Options Impact Stock Volatility? Empirical Evidence from Underlying Stocks in Indian Market. Theoretical Economic Letters, 8, 1803-1815. https://doi.org/10.4236/tel.2018.810118

[23] French, K. and Roll, R. (1988) Stock Returns Variances: The Arrival of Information and the Reaction of the Traders. Journal of Financial Economics, 17, 5-26. https://doi.org/10.1016/0304-405x(86)90004-8

[24] Roll, R. (1988) R2. The Journal of Finance, 43, 541-566. https://doi.org/10.1111/j.1540-6261.1988.tb04591.x 